\title{
Move beyond differences
}

\section{Researchers and ethicists need to see past what can seem to be gendered debates when it comes to the governance of biotechnology, says Charis Thompson.}

$\mathrm{T}$ his autumn, researchers and other experts will come together to discuss the scientific, ethical and policy issues associated with gene-editing research in humans. Plans for the international meeting were announced by the US National Academy of Sciences and the National Academy of Medicine after a study was published in which researchers used a gene-editing tool known as CRISPR to modify the genomes of non-viable human embryos ${ }^{1}$.

Whether this meeting and others like it, planned in the United States, can help to forge a path for gene editing that takes into account all the relevant needs and concerns will depend on what efforts are made to integrate the diverse perspectives of people with different expertise and values. A first step to such integration is understanding how different perspectives arise.

One division in cares and concerns seems at times to fall along stereotypical gender lines. This was powerfully demonstrated during a meeting in Atlanta, Georgia, last month on biotechnology and ethics. About 200 global thought leaders gathered at BEINGS 2015 to "reach consensus on the direction of biotechnology for the twentyfirst century". On the day I attended, it was generally men who focused on containing biosecurity threats and on how to prevent regulation from impeding research. Women raised concerns about eugenics and class, race and gender inequalities in relation to biotechnology. Women were also the ones discussing the environment, the future of humanity, and the possible harms to the people who supply materials such as tissues and eggs, on which advances in biotechnology rely.

People at the conference quipped that this gendered divide reflected the following: men are pro-science and women are pro-ethics; men draw on rational criteria to support their arguments whereas women draw on emotional ones; men are interested in tangible, pragmatic issues whereas women are interested in values and deep ethical thought.

All of these ideas are reductive and sexist. They fail to recognize that people - whatever their gender, race or class - generally focus on pragmatic and measurable solutions to the problems they find the most pressing. People just differ on which issues they think are the most important.

That men and women at BEINGS tended to focus on different concerns reflected underlying differences of opinion about what needs to be taken into account when considering whether and how a particular area of science should proceed. These underlying differences are themselves gendered, because gender still affects which fields and subfields people enter, who does what kind of professional and domestic work, and where people's political concerns lie $^{2}$.

Take questions of framing, governance and jurisdiction. When framing the problems, people in one camp tend to see cures for disease as a morally unassailable good underlying the investment and effort currently being channelled into technological advances. The

\section{"People generally focus on pragmatic and measurable solutions to the problems they find the most pressing."} people in this camp generally believe that biotechnology (and science in general) should primarily be self-policing. They also tend to perceive non-experts and scholars with different areas of expertise as outsiders who slow down or stifle research.

For those in the other camp, the worth of scientific breakthroughs should be judged in a broader social context: addressing certain problems, such as entire populations being medically underserved, should be an integral part of the responsible development of biotechnology. People in this camp also tend to believe that the governance of biotechnology should be shaped according to how and where biotechnology is developed and deployed, for whom and at what cost - and that a greater diversity of experts, and many more nonexperts, should be involved.

Obviously, there is not a clean twogendered split, with men neatly falling into one camp and women into the other. Multiple genders, sexualities and family structures are increasingly being recognized worldwide, biologically and politically. Numerous scholars have shown that the

\begin{tabular}{ll|} 
CRISPR GENE EDITING \\
A Nature collection \\
nature.com/crispr
\end{tabular}

effects of a person's gender on their choice of work, politics and so on can be understood only if their class, race, sexuality, disability and citizenship are also considered (see, for example, ref. 3). Nonetheless, differences in approaches to bioethics come out in a gendered way because the factors that shape views of the appropriate scope and nature of science governance are themselves gendered.

Currently, there is a tendency for some scientists, bioethicists, lawyers, patient advocates and others to regard as 'woolly' people who are concerned with issues such as health disparities. Equally, those who take a broader view of biotechnology's responsibility perceive some scientists as too caught up in the monetization and competition of their fields. These views often manifest as a perceived deficit in rationality in the other camp.

When scientific developments throw up difficult choices, scientists, social scientists and others need to stop positioning other people as being for or against science, or for or against ethics.

Mechanisms are needed to ensure that neither camp dominates the other. Following the autumn meeting, the National Academy should establish working groups to study and document at regular intervals the wide range of phenomena that will shape and be shaped by gene-editing research - from scientific breakthroughs to health disparities and disability justice.

If specialist pursuit of certain issues in such working groups is combined with efforts to bring the diverse strands of understanding together, for instance in the same publications, we might end up with better science and better ethics.

Charis Thompson is professor and chair in the Department of Gender and Women's Studies, University of California, Berkeley, California, USA, and professor in the Department of Sociology, London School of Economics, UK. She is the author of Making Parents and Good Science. e-mail:charis@berkeley.edu

1. Liang, P. et al. Protein Cell 6, 363-372 (2015).

2. European Commission. She Figures 2012 : Gender in Research and Innovation - Statistics and Indicators (Publications Office of the European Union, 2013).

3. Grzanka, P. R. (ed.) Intersectionality: A Foundations and Frontiers Reader (Westview, 2014). 